\title{
Implementation of performance assessment in STEM-based science learning to improve students' habits of mind
}

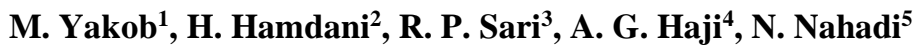 \\ ${ }^{1}$ Department of Physic Education, Universitas Samudra, Indonesia \\ ${ }^{2}$ Department of Mechanical Engineering, Universitas Samudra, Indonesia \\ ${ }^{3}$ Department of Chemistry Education, Universitas Samudra, Indonesia \\ ${ }^{4}$ Department of Science Education, Universitas Syiah Kuala, Indonesia \\ ${ }^{5}$ Department of Chemistry Education, Universitas Pendidikan Indonesia, Indonesia
}

\section{Article Info}

Article history:

Received Sep 29, 2020

Revised Mar 14, 2021

Accepted Apr 13, 2021

\section{Keywords:}

Habits of mind

Performance assessment

STEM learning

\begin{abstract}
This study described the implementation of STEM-based science learning and performance assessment to the improvement of students' thinking skill in Aceh, Indonesia. The purposive sampling technique was employed in this descriptive research. The respondents were 300 students at grade 11th academic year 2019/2020 which representing five public high schools in Aceh, Indonesia. The instruments used to measure the effectiveness of the implementation of STEM-based science learning were the rubric of habits of mind, observation sheets of performance assessments, and questionnaires. The finding presented the implementation of STEM-based science learning was able to habituate and develop students' habits of mind with an average score of 0.71 which included into high category. The average value of the overall STEM-based science learning implementation for the formation of habits of mind is $95.98 \%$ which categorized as good. It can be concluded that there is the success of researchers in implementing STEM-based science learning to form students' habits of mind.
\end{abstract}

This is an open access article under the CC BY-SA license.

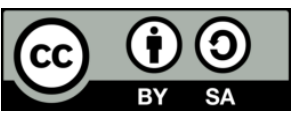

Corresponding Author:

R. P. Sari

Department of Chemistry Education

Universitas Samudra

Langsa City, Aceh 24416, Indonesia

Email: ratihps@unsam.ac.id

\section{INTRODUCTION}

The 21 st century has become the main basis for various aspects of modern human life. The development of the 21 st century is marked by the use of technology, communication and information which applied to everyday life. The dependence of all aspects of life on current technology has led to changes in the qualifications and competencies of an increasingly competitive workforce [1], [2].

The result of international assessment of Trends in International Mathematics and Science Study (TIMSS) and Programme for International Student Assessment (PISA) showed the low achievement of Indonesian students' scientific literacy. Indonesia was ranked 40th out of 42 countries in the TIMSS 2011 and was ranked 64th out of 65 countries in the 2012 PISA assessment. It illustrates that the practice of education in Indonesia is still far from expectation [3], [4]. One of the obstacles which affect the low achievement of Indonesian students in the international assessment is the learning strategy used. Many of the lessons are carried out in formal schools by the conventional learning strategies. Since the conventional teaching is less providing students to be actively engage in the learning process, a new approach of delivering 
lesson is must be improved. In science, one of the suitable learning approaches which able to be applied is the Science Technology Engineering Mathematics (STEM) approach. The STEM approach supported students to be not only taught in theory, but also involve in practical activities like make projects, so that students experience the hands-on and minds-on activity which accordance with the nature of Science [5], [6]. However, in STEM-based learning, the implementation of science learning and project-based evaluation is different from what is commonly used. In Indonesia, especially in Aceh Province, STEM-based learning has not been popular when compared to developed countries, such as the United States [7]. However, the government is starting to notice the STEM learning to be implemented in the school curriculum [8]-[10]. The STEM-based learning in Indonesia is still in a developing stage, and currently there is no standard assessment that can be applied [11]. Assessment of learning outcomes in the context of STEM-based science learning needs to focus more on authentic assessments, especially performance assessments.

STEM education provides opportunities for teachers to show students how concepts, principles and techniques from science, technology, engineering, and mathematics are used in an integrated manner in the development of products, processes and systems used in their daily lives. Therefore, previous studies [12][14] adopt the definition of STEM education as an interdisciplinary approach to learning, in which students use science, technology, engineering, and mathematics in real contexts that connect schools, the world of work, and the global world, thus developing STEM literacy that enables students to compete in a new knowledge-based economic era. In addition, STEM learning provides direct learning experiences to students about mastery of knowledge, attitudes, and skills to identify questions and problems in student life.

Science could be categorized as the product and as a process. The science as a product includes a collection of knowledge of facts, concepts and principles of science, while science as a process includes skills and positive attitudes that students have to achieve science products. The attitude of students to achieve scientific products can be pursued with a scientific attitude and habits of active thinking in learning. The habit of positive thinking in teaching and learning activities can form the habits of mind of students to achieve their success of learning. Chemistry has an important role in forming students' habits of mind in the learning process and in creating scientific products in a scientific manner. Habits of mind in chemistry lessons can be described as the students' habits of active thinking, creative thinking, critical thinking and how students can make their own understanding of knowledge [15]. Several studies [16]-[18] have shown that habitual thoughts can become patterns intelligent behavior that makes it possible an action that is productive and capable of producing positive student character in solving problems in their life. Habits of mind inside one's behavior requires a deep level of discipline a mind that can be trained and shaped in such a way, so it can become a habit to continue trying to do wiser and smarter. This can be a form of action done by someone who is a consequence of his habitual thought. When facing problems, students tend to form patterns of behavior certain intellectuals who can encourage individual success in completing the problem. This is reinforced with the opinion of Aristotle [19] which revealed that individual success is largely determined by habits he does. Therefore, it is the habits of mind someone has will affect success, one of which is his success in studying chemistry at school. Recently, teachers who carry out learning in class encounter several students who have good intellectual intelligence but lack the ability to behave. There are some students who are smart in describing concepts, intelligent in mathematical calculations, but are less able to communicate and cooperate with their friends, do not have empathy, and if they encounter difficulties, they are easy to give up.

The performance assessment also plays an important role in improving students' habits of mind. STEM-based performance assessment is one of the assessment tools that must also be used in science learning, especially in terms of revealing student skills. This assessment is not only be used to assess learning outcomes or products, but can also be used as part of learning. This formative assessment can measure students' knowledge, reasoning skills, products, and multiple intelligences. Based on the problems have described, it is necessary to analyze the implementation of STEM-based science learning and performance assessment to measure students' thinking skills in public high school students in Aceh Province. The purpose of this study was to describe the implementation of STEM-based science learning and performance assessment to the improvement of students' habits of mind in Aceh Province, especially during the COVID19 pandemic.

\section{RESEARCH METHOD}

\subsection{Research sample}

This research employed descriptive quantitative design. Descriptive research attempts to describe a symptom, event, and event that is occurring at the present time [20]. Population of this study was student at grade 11th of public high schools in Aceh, Indonesia academic year 2019/2020. The sample was collected by purposive sampling technique. The sample size was 300, consisted of male and female students representing 
five public high schools in each district in Aceh Province, namely SMA Negeri 1 Langsa, SMA Negeri 1 Lhokseumawe, SMA Negeri 1 Banda Aceh, SMA Negeri 3 Banda Aceh and SMA Negeri 1 Bireun.

\subsection{Instrument and data analysis technique}

The data in this study consist of two types, namely:

a. Needs analysis data, namely data on students' initial needs regarding to the material to be applied in STEM-based science learning which collected through interviews with science teachers in each Aceh district.

b. Students' scientific performance data which obtained from observation sheets filled out by observers during the implementation of STEM learning, student performance assessment is carried out through small and large-scale tests, small-scale tests are conducted at SMA Negeri 1 Langsa and large-scale tests are conducted in four schools representatives in Aceh Province.

c. Students' responses data to the implementation of STEM-based science learning which obtained from the questionnaire which conducted at the end of the lesson.

Student habits of mind obtained from the results of implementing STEM-based learning which collected through a rubric. Habits of mind rubric was adopted and developed from Sriyati [21]. This rubric consists of several questions consisting of three categories of self-regulation, creative thinking and critical thinking. The statement in the rubric was measured by the Likert scale with the interval (4) to (1). The rubric sheet is filled in by all students involved in the research. The filling of the rubric is done by giving a cross in the column of interval numbers to describe the thinking habits of students before and after the learning process. Students' habits of mind data were analyzed using the rubric from Marzano, Pickering, and McTighe [22]. The grid habits of minds can be seen in Table 1.

Table 1. Habits of mind rubric outline

\begin{tabular}{|c|c|c|c|}
\hline No. & Indicator & Rated aspect & Number of statements \\
\hline 1 & Self-regulation & $\begin{array}{l}\text { a. Aware of own thoughts } \\
\text { b. Make plans selectively } \\
\text { c. Aware of and use the relevant sources } \\
\text { d. Sensitive to the feedback } \\
\text { e. Evaluate the effectiveness of the action }\end{array}$ & $1,2,3,4$ and 5 \\
\hline 2 & Critical thinking & $\begin{array}{l}\text { a. Accurate and seek accuracy } \\
\text { b. Clear and seek clarity } \\
\text { c. Open minded } \\
\text { d. Refrain from impulsivity } \\
\text { e. Able to take position when there is a guarantee } \\
\text { f. Sensitive and know the ability of their friends }\end{array}$ & $6,7,8,9,10$ and 11 \\
\hline 3 & Creative thinking & $\begin{array}{l}\text { a. Make an effort to continuously complete the task even though } \\
\text { the answer is not predictable } \\
\text { b. Encourage yourself to try something you're not sure you can do } \\
\text { c. Produce, trust, and use standards for evaluation of the work } \\
\text { d. Creating a new perspective which different from the general } \\
\text { perspective }\end{array}$ & $12,13,14$ and 15 \\
\hline
\end{tabular}

Data processing and analysis of habits of mind improvement was carried out by comparing the initial and final habits of mind rubric scores. To determine the increase in thinking skills, the N-Gain formula is used as:

$$
\mathrm{N}-\text { Gain }=\left[\frac{\mathrm{N}_{\mathrm{B}}-\mathrm{N}_{\mathrm{A}}}{\mathrm{N}_{\mathrm{MAX}}-\mathrm{N}_{\mathrm{A}}}\right] \mathrm{X} 100 \%
$$

Where: $\mathrm{N}_{\mathrm{A}}=$ initial habits of mind; $\mathrm{N}_{\mathrm{B}}=$ final habits of mind; $\mathrm{N}_{\mathrm{MAX}}=\mathrm{ideal}$ habits of mind.

The criteria of the improvement of student' habits of mind is indicated by the gain index obtained in the initial and final rubrics. This criteria is presented in Table 2.

Table 2. N-gain score category of students' habits of mind

\begin{tabular}{cc}
\hline Range & Category \\
\hline $\mathrm{g}>0.70$ & High \\
$0.30 \leq \mathrm{g} \leq 0.70$ & Moderate \\
$\mathrm{g}<0.30$ & Low \\
\hline
\end{tabular}




\section{RESULTS AND DISCUSSION}

Data analysis of the needs of science learning materials obtained from interviews with teachers are presented in Table 3. Table 3 reveals that the science material which will be applied in STEM-based learning are additive and addictive substances in the first level with the total responses $85 \%$, followed by acid-base material, vibrations and waves as well as plant structure and function by $80 \%$. The data of students' Habits of Mind in Aceh province after implementing STEM-based science learning were obtained from N-Gain by reducing the final rubric score with the initial test score, then dividing with the maximum ideal score and subtracting the initial test score. The data are displayed in Table 4 and Figure 1.

Table 3. The needs of science learning materials from interviews with teachers

\begin{tabular}{cc}
\hline Learning materials & Percentage $(\%)$ \\
\hline Motion of living things and beings & 65 \\
Work and simple aircraft & 75 \\
Structure and function of plants & 80 \\
Human digestive system & 75 \\
Additives and addictive & 85 \\
Acid base & 80 \\
Vibrations and waves & 80 \\
\hline
\end{tabular}

Table 4. N-gain score of habits of mind through the implementation of STEM-based science learning

\begin{tabular}{clccccc}
\hline \multirow{2}{*}{ No } & \multirow{2}{*}{ Science learning material } & Self-regulation & $\begin{array}{r}\text { N-Gain Score } \\
\text { Critical thinking }\end{array}$ & Creative thinking & Average & Category \\
\hline 1 & Additives and addictive & 0.72 & 0.77 & 0.68 & 0.72 & High \\
2 & Acid base & 0.68 & 0.75 & 0.67 & 0.70 & Moderate \\
3 & Vibration and waves & 0.65 & 0.70 & 0.72 & 0.69 & Moderate \\
4 & Structure and function of plants & 0.70 & 0.68 & 0.77 & 0.72 & High \\
& Total score & & & 0.71 & High \\
\hline
\end{tabular}

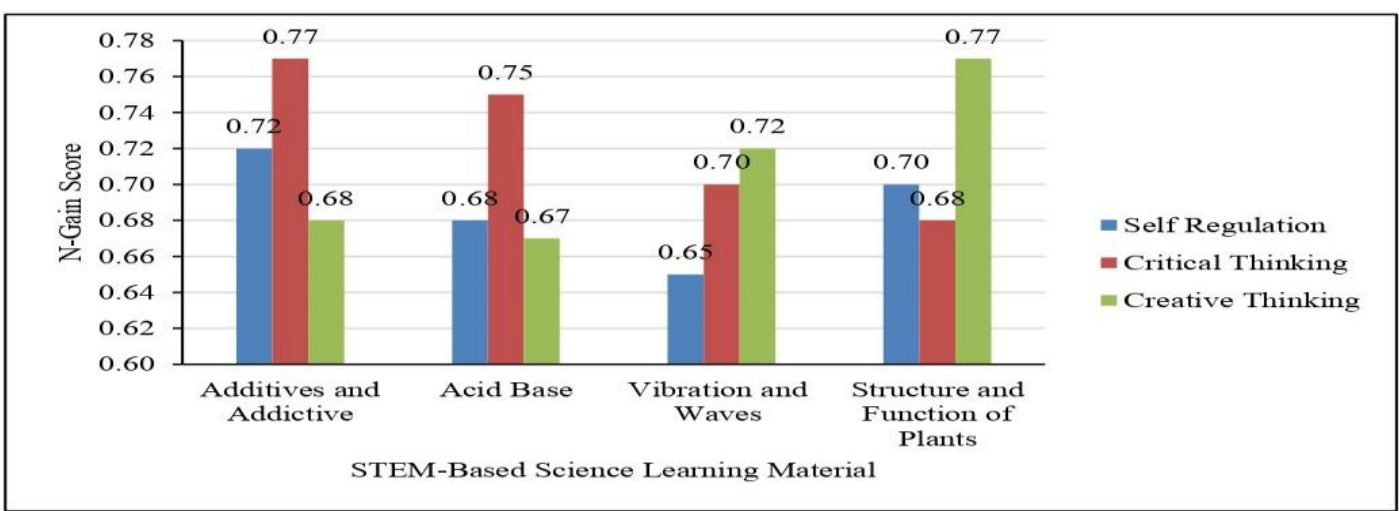

Figure 1. The implementation of STEM-based science learning to the improvement of habits of mind

Table 4 and Figure 1 show each material provides different results of the improvement in the habits of mind of students. Additive and addictive substances as well as structure and function of plant had the highest score among other materials with an average score of 0.72. It means that the application of the STEM-based science learning provides a high contribution to improve students' habits of mind. Additive and addictive substances give a high contribution to students' critical thinking skill, followed by self-regulation and creative thinking skill. During the learning process students are instructed to actively thinking to solve problems, collect the information, processing and make conclusion through the animated media shown. In addition, during the learning process the students have curiosity, active in asking questions and are able to communicate with friends in explaining the material they are presenting. In the learning process students are able to work together and able to hypothesize about the problems at hand. This is in accordance with previous research where students become active in the search and decision-making process by increasing their critical thinking skills [23], [24]. Indicators of critical thinking skills revealed that most of situations which requiring problem solving achieved the highest average score [25]. Moreover, critical thinking skills are widely known as essential skills [26]-[28]. 
In the material structure and function of plants, Table 4 shows the high influence of STEM-Based learning on students' creative thinking skill. The learning carried out in laboratory makes it easy for students to work together, find new answers to every problem and be able to solve problems without looking back at the experiment. This is in accordance with research by Magsino [29] and Daud, et al. [30], where the science learning model is able to provide opportunities for students to be more active in the learning process where students are encouraged to have experience in conducting experiments that allow them to find principles or knowledge by themselves with guidance from the teacher.

In acid-base and wave material, students still have problems in preparing project assignments and exploring e-learning-based materials so that they get the lowest gain value compared to other learning materials. This is due to the availability of project material that must be prepared by students, the availability of time to complete the project, as well as the lack of teachers to guide students in working on projects. Basically, STEM-based learning principles include contexts to involving students in the extension of authentic inquiry through introductory questions, collaborative work that allows students to communicate their ideas, learning technology to find and convey solutions and from these activities creating products that students will demonstrate as a basis for discussion, feedback, and revision [31], [32].

The relevant research showed that the application of the STEM-based science learning is able to habituate and develop the students' skills to solve problems that are oriented towards authentic problems from students' actual lives and stimulate higher-order thinking skills. In line with [33]-[37] learning by integrating STEM will bring positive impact on students' learning process. The data on the application of students' performance assessments were collected during the experiment process. The data on students' performance assessment in improving habits of mind can be seen in Figure 2.

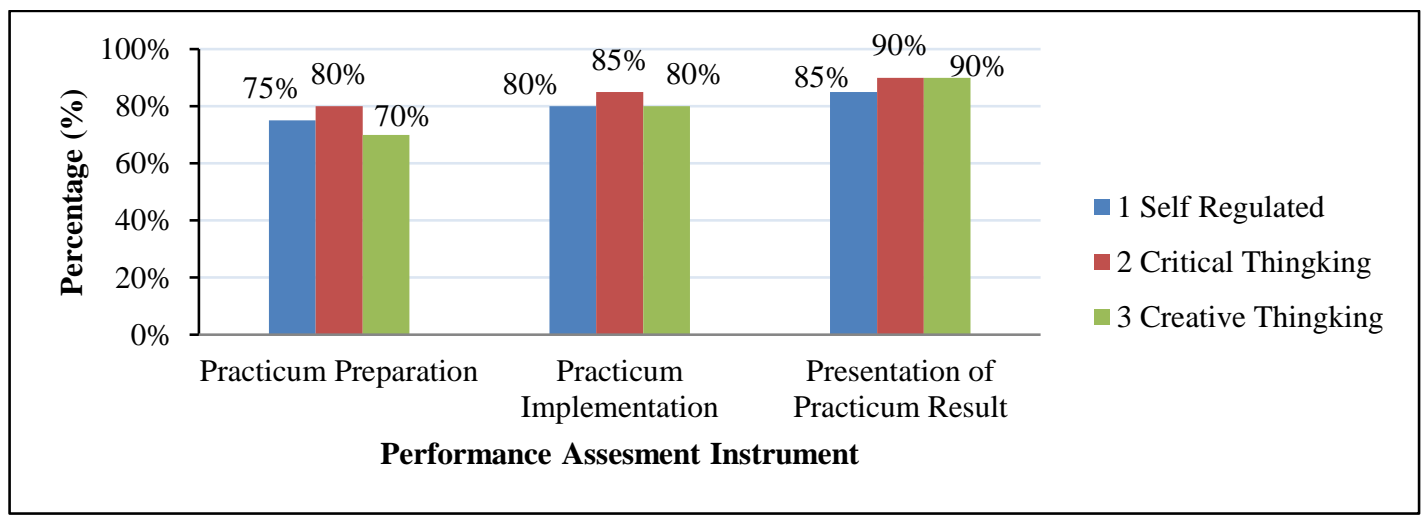

Figure 2. The implementation of performance assessment on the improvement of habits of mind

Figure 2 illustrates an improvement in students' Habits of Mind in the process of implementing performance assessment from the experiment preparation stage to the end stage of the presentation of the experiment results. The highest performance was found in indicators of creative thinking by $20 \%$, followed by critical thinking and self-regulated students. The purpose of this performance assessment is to measure the skill which includes the ability to observing, trying, asking, reasoning, presenting and creating. However, these skills are neither inborn nor naturally acquired, yet must be trained in students [38], [39] This is in accordance with research [40] which states that the use of performance assessment should be carried out to measure psychomotor aspects (product performance and process performance) and be able to provide reliable measurement and assessment results.

Furthermore, at the end of the lesson, students are given a questionnaire on the application of the STEM-based science learning model to measure students' interest in the learning process being implemented. Student responses can be used as a reflection for the teacher on the learning model that has been used. In this study students gave a positive response to the application of the STEM-based science learning model in improving habits of mind. The result is shown in Figure 3.

Figure 3 informs that the student's response to the material taught using STEM shows a positive response, especially on each indicator of habits of mind. This means that respondents agree with the application of this learning model, especially in training and shaping students' habits. Likewise with the application of this learning model to the material provided, students agree that the learning carried out is adjusted to their daily lives so that many new problems can be solved by students. The average percentage of 
the overall STEM-based science learning model for the formation of habits of mind is $95.98 \%$ or categorized as good, so that the student's response can indicate that the researchers 'success in implementing STEMbased science learning to form students' habits of mind. This is in line with Stohlmann, et al. [41] through integrated science learning STEM can give the impression of an interesting and not boring learning. The results of this study are also in line with Hashim, Ali, and Samsudin [42]. They found that the habits of the mind depend on the classroom environment, a good learning environment, where teachers are responsible for providing a good learning environment and develop productive habits of mind. In other words, develop productive habits of mind depending on the teacher and their awareness and knowledge. Therefore, in preparing students for lifelong learning, skills are needed to behave intelligently when they are faced with a problem that is not immediately answered known.

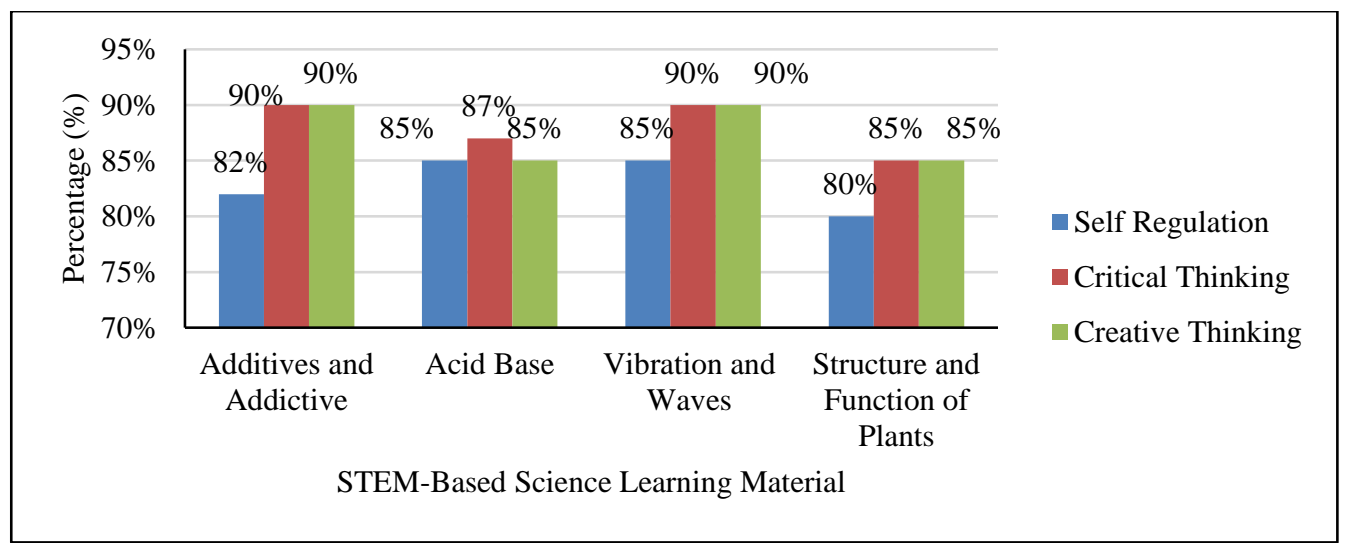

Figure 3. The percentage of questionnaire results through the application of a STEM-based science learning to the habits of mind indicator

\section{CONCLUSION}

This research found that additive and addictive substances as well as structure and function of plant had the highest score among other materials with an average score of 0.72 . It means that the application of the STEM-based science learning provides a high contribution to improve students' habits of mind. In acidbase and wave material, students still have problems in preparing project assignments and exploring elearning-based materials so that they get the lowest gain value compared to other learning materials. This is due to the availability of project material that must be prepared by students, the availability of time to complete the project, as well as the lack of teachers to guide students in working on projects. Habits of mind in the process of implementing performance assessment from the experiment preparation stage to the end stage of the presentation of the experiment results. The highest performance was found in indicators of creative thinking by $20 \%$, followed by critical thinking and self-regulated students. The average percentage of the overall STEM-based science learning model for the formation of habits of mind is $95.98 \%$ or categorized as good. The student's response indicated that the researcher's success in implementing STEMbased science learning to form students' habits of mind.

\section{ACKNOWLEDGEMENTS}

This work was financially supported by Lembaga Penelitian, Pengabdian kepada Masyarakat dan Penjaminan Mutu (LPPP-PM) of the Samudra University, Unsyiah University and UPI University through Penelitian Dosen Unggulan (PDU) 2020 with Chancellor's Decree No. 545/UN54.6/PG/2020.

\section{REFERENCES}

[1] A. Septiani, "Application of Performance Assessment in the STEM (Science, Technology, Engineering, Mathematics) to Uncover Science Process Skills," (in Bahasa), Seminar Nasional Pendidikan dan Saintek 2016, Isu-isu Kontemporer Sains, Lingkungan, dan Inovasi Pembelajarannya, vol. 1, 2016, pp 654-659.

[2] L. Bao and K. Koenig, "Physics Education Research for 21st Century Learning," Disciplinary and Interdisciplinary Science Education Research, vol. 1, pp. 1-12, 2019, doi: 10.1186/s43031-019-0007-8.

[3] Ministry of Education and Culture of Republic Indonesia. Supporting Materials for Science Literacy, (in Bahasa). Kemendikbud: Jakarta. 2017. 
[4] L. Hewi and M. Shaleh, "PISA (The Programme for International Student Assesment) Reflection: Improvement Efforts Rests on Early Childhood Education," (in Bahasa), Jurnal Golden Age, vol. 4, no. 1, pp. 30-41, 2020.

[5] A. Permanasari, "STEM Education: Innovation in Science Learning," (in Bahasa), Prosiding Seminar Nasional Pendidikan Sains (SNPS), vol. 1, 2016, pp. 24-34.

[6] C. Tanenbaum, STEM 2026: A vision for innovation in STEM education. Washington, DC: US Department of Education. 2016

[7] A. Adlim, S. Saminan and A. Siska, "Development of Entrepreneurship Integrated STEM Module to Improve Science Process Skills at SMA Negeri 4 Banda Aceh," (in Bahasa), Indonesian Journal of Science Education, vol. 3, no. 2, pp. 112-121, 2015.

[8] H. B. Gonzalez and J. J. Kuenzi, "Science, Technology, Engineering, and Mathematics (STEM) Education: A Primer," Congressional Research Service, vol. 1, pp. 1-27, 2012.

[9] N. Khaeroningtyas, A. Permanasari, and I. Hamidah, "STEM Learning in Material of Temperature and Its Change to Improve Scientific Literacy of Junior High School Students," Jurnal Pendidikan IPA Indonesia, vol. 5, no. 1, pp. 94-100, 2016.

[10] K. Koenig, M. Schen, M. Edwards, and L. Bao, "Addressing STEM retention through a scientific thought and methods course," Journal of College Science Teaching, vol. 41, no. 4, pp. 23-29, 2012.

[11] O. F. Nugroho, A. Permanasari and H. Firman, "The Movement of STEM Education in Indonesia: Science Teachers' Perspectives," Indonesian Journal of Science Education, vol. 8, no. 3, pp. 417-425, 2019.

[12] Y. Zhang, S. Wang, H. Xia, and J. Ge, "A Novel SVPWM Modulation Scheme," in 2009 Twenty-Fourth Annual IEEE Applied Power Electronics Conference and Exposition, 2009, pp. 128-131.

[13] T. Mujtaba, R. Sheldrake, M. J. Reiss, and S. Simon, "Students' science attitudes, beliefs, and context: associations with science andchemistry aspirations," International Journal of Science Education, vol. 40, no. 6, pp, 644-667, 2018.

[14] A. T. Twiningsih, "Improving Student Learning Outcomes Through Stem-Based Magic Box Medium in The Concept of Addition Theory," International Journal of Research in STEM Education (IJRSE), vol. 2, no. 1, pp. 79-90, 2020

[15] R. P. Sari, M. P. Hasibuan, A. G. Haji, Nahadi, and Sofiyan, “A Development of Project Based Learning (PBL) Chemistry Worksheet to Form Students' Habits of Mind," Journal of Physics: Conference Series, vol. 1460, pp. 1-9, 2020.

[16] G. Dwirahayu, D. Kustiawati, and I. Bidari, "Corresponding Habits of Mind and Mathematical Ability," Journal of Physics: Conference Series, vol. 895, pp. 1-6, 2017.

[17] I. Rakhmawati, N. Hasnunidah, and M. A. Priadi, "Habits of Mind and Concept Mastery of Cell in Multimedia Virtual Class Environment: A Case of Biology Students in Lampung University," Jurnal Pendidikan MIPA, vol. 20, no. 1, pp. 17-22, 2019.

[18] N. Nahadi, H. Firman, and J. Farina, "Effect of Feedback in Formative Assessment in The Student Learning Activities on Chemical Course to The Formation of Habits of Mind," Indonesian Journal of Science Education, vol. 4, no. 1, pp. 35-42, 2015.

[19] B. Miliyawati, "The Urgency of Mathematical Habits of Mind Disposition Strategies," (in Bahasa), Infinity: Jurnal Ilmiah Program Studi Matematika STKIP Siliwangi Bandung, vol. 3, no. 2, pp. 174-188, 2014.

[20] Sugiyono, Educational Research Methods (Quantitative, Qualitative and R\&D Approaches), (in Bahasa). Bandung: Alfabeta, 2018.

[21] S. Sriyati, "The Role of Formative Assessment in Forming Habits of Mind of Biology Students," (in Bahasa), Dissertation, Universitas Pendidikan Indonesia, 2011.

[22] R. J. Marzano, D. Pickering, and J. McTighe, "Assessing Student Outcomes: Performance Assessment Using the Dimensions of Learning Model," Mid-Continent Regional Educational Lab., Aurora, CO., 1993.

[23] B. Utami, S. Saputro, A. Ashadi, M. Masykuri, and S. Widoretno, "Critical Thinking Skills Profile of High School Students in Learning Chemistry," Int. J. Sci. Appl. Sci.: Conf. Ser., vol. 1, no. 2, pp. 124-130, 2016.

[24] K. Becker and K. Park, "Effects of Integrative Approaches Among Science, Technology, Engineering, and Mathematics (STEM) Subjects on Students' Learning: A Preliminary Meta-Analysis," Journal of STEM Education, Vol. 12, pp. 23-37, 2011.

[25] N. Bahr, "Thinking critically about critical thinking in higher education," International Journal for the Scholarship of Teaching and Learning, vol. 4, pp. 1-16, 2010.

[26] S. Bell, "Project-based learning for the 21st century: Skills for the future," The Clearing House: A Journal of Educational Strategies, Issues and Ideas, Vol. 83, pp. 39-43, 2010.

[27] M. Karakoç, "The Significance of Critical Thinking Ability in Terms of Education," International Journal of Humanities and Social Science, Vol. 6, no. 7, pp. 81-84, 2016.

[28] K. Changwong, A. Sukkamart, and B. Sisan, "Critical Thinking Skill Development: Analysis of A New Learning Management Model for Thai High Schools," Journal of International Studies, Vol. 11, no. 2, pp. 37-48, 2018.

[29] R. M. Magsino, "Enhancing Higher Order Thinking Skills in A Marine Biology Class Through Problem Based Learning," Asia Pacific Journal of Multidisciplinary Research, vol. 2, no. 5, pp. 1-6, 2014.

[30] A. M. Daud, J. Omar, P. Turiman, and K. Osman "Creativity in Science Education," Procedia - Social and Behavioral Sciences, Vol. 59, pp. 467-474, 2012.

[31] R.W. ByBee, "Advancing STEM education: A 2020 vision," The Technology and Engineering Teacher, Vol. 70, no. 1 , pp. 30-35, 2010. 
[32] K. Becker and K. Park, "Effects of Integrative Approaches Among Science, Technology, Engineering, And Mathematics (STEM) Subjects on Students' Learning: A Preliminary Meta-Analysis," Journal of STEM Education, Vol. 12, no. 6, pp. 23-37, 2011.

[33] P. A. Asunda and J. Weitlauf, "STEM Habits of Mind: Enhancing a PBL Design Challenge--Integrated STEM Instruction Approach," Technology and Engineering Teacher, Vol. 78, no. 3, pp. 34-38, 2018.

[34] N. W. Suarniati, N. Hidayah, and D. Handarini, "The development of learning tools to improve students' critical thinking skills in vocational high school," IOP Conference Series: Earth and Environmental Science, vol. 175, pp. 1-7, 2018.

[35] I. Z. Ichsan, D. V. Sigit, and M. Miarsyah, "Environmental Learning Based on Higher Order Thinking Skills: A Needs Assessment," International Journal for Educational and Vocational Studies, Vol. 1, no. 1, pp. 21-24, 2019.

[36] T. Gok, "The General Assessment of Problem-Solving Processes and Metacognition in Physics Education," Eurasian Journal Physics Chemistry Education, Vol. 2, pp. 110-122, 2010.

[37] S. R. Yuliati and I. Lestari, "Higher-Order Thinking Skills (Hots) Analysis of Students in Solving Hots Question in Higher Education," PERSPEKTIF Ilmu Pendidikan, Vol. 32, pp. 181-188, 2018.

[38] K. Ulger, "The effect of problem-based learning on the creative thinking and critical thinking disposition of students in visual arts education," Interdisciplinary Journal of Problem-Based Learning, Vol. 12, no. 1, 2018.

[39] M. Sobhanzadeh, C. S. Kalman, and R. I. Thompson, "Labatorials in introductory physics courses," European Journal of Physics, Vol. 38, pp.1-18, 2017.

[40] N. Budiwaluyo, R. Asyhar, and B. Hariyadi "The Development of Performance-Assessment Instrument on Cell Structure and Function Experiment at SMA Negeri 1 Kota Jambi,” (in Bahasa), Edu-Sains., Vol. 5, no. 2, pp. 1-7, 2016.

[41] M. Stohlmann, J.M. Tamara, and H.R. Gillian, "Considerations for Teaching Integrated STEM Education," Journal of Pre-College Engineering Education Research (J-PEER), Vol. 2, no. 1, pp. 22-29, 2012.

[42] H. Hashim, M.N. Ali, and M.A. Samsudin, "Nurturing Habits of Mind (HOM) Through Thinking Based Learning (TBL) in Doing Science Technology, Engineering and Mathematics (STEM) Project," EDUCATUM JSMT, Vol. 5, pp.7-18, 2018. 